\title{
Mind Skills Training Model through Experiential Learning as Guide Teacher and Islamic Counselors
}

\section{Supa'at}

IAIN Kudus

supaat@stainkudus.ac.id,

Khilman Rofi' Azmi

IAIN Kudus

rofiazmi@iainkudus.ac.id

\begin{abstract}
This article is aimed to create mind skills training manual books for guidance teachers and counselors to increase counseling skills theoretically and practically. Mind skill used by counselors and guides teachers in MTs 1 Kudus, MTs TBS, and Muhammadiyah Kudus, Central Java to manage and think about what they think and do. It will implicate how they react and act, communicate, and respond to their counselee or client. This article used a development approach that modified from Borg and Gall model through three phases included (1) preparation, (2) implementation, and (3) trial. The mind skills training book was developed by referring to the needs of research subjects based on the results of interviews and literature studies. The result shows that the mind skills manual book for guide teacher counselor is accepted and fulfillment with an average value of $87 \%$ in the "very good" category for small group tests by corresponding of correctness, usefulness, and conformity aspect.
\end{abstract}

Keywords: mind skills; guide; Islamic counselor; training; research and development; very good

\begin{abstract}
Abstrak
Artikel ini bertujuan untuk membuat buku panduan pelatihan keterampilan pikiran untuk guru bimbingan dan konselor dalam rangka meningkatkan keterampilan konseling secara teoritis dan praktis. Keterampilan pikiran digunakan oleh konselor dan membimbing guru di MTs 1 Kudus, MTs TBS, dan Muhammadiyah Kudus, Jawa Tengah untuk mengelola dan berpikir tentang apa yang mereka pikirkan dan lakukan. Ini akan melibatkan bagaimana mereka bereaksi dan bertindak, berkomunikasi, dan menanggapi konseli atau
\end{abstract}


klien mereka. Artikel ini menggunakan pendekatan pengembangan yang dimodifikasi dari model Borg dan Gall melalui tiga fase termasuk (1) persiapan, (2) implementasi, dan (3) percobaan. Buku pelatihan keterampilan pikiran dikembangkan dengan merujuk pada kebutuhan subyek penelitian berdasarkan hasil wawancara dan studi literatur. Hasil penelitian menunjukkan bahwa buku panduan keterampilan pikiran untuk guru BK membimbing diterima dan dipenuhi dengan nilai rata-rata 87\% dalam kategori "sangat baik" untuk tes kelompok kecil dengan aspek ketepatan, kegunaan, dan kesesuaian. Kata kunci: keterampilan pikiran; konselor Islam;pedoman, R \& D, sangat baik

\section{Introduction}

This study was conducted to answer the problem of the difficulty of applying mind skills of counselor and guide teacher. This problem will be pursued in the form of problem solving by developing a guide for thinking skills to improve the quality of counseling. The guide in the form of a guidebook is intended for prospective counselors and guides the teacher.

Mind skills are skills that related to the counselor's mental process when they are counseling people. Counseling is an activity, not only tangible but also involves mental processes that can influence what the counselor does before, during, and after counseling activities. 1 Interpreted mind skills as a set of counselor skills for managing the mind and rethinking thought at the same time being done, so it will have implications for how counselors behave, communicate, and respond to counselees. Mind skills refer to the internal abilities that the counselor musthave. Internalizing the mind skills is not easy because every guide teacher and counselor is unable to use this skill. Therefore, a manual or module is needed to give specific directions for prospective counselors to use the thinking paradigm by using mind skills.

1 R.N. Jones, Introduction to Counseling Skill (London: SAGE Publications, Inc., 2005). 
As a reflective practitioner, the counselor always thinks and reviews the actions he has taken. The results of reflection are used as a basis for counselors to improve and develop themselves so that they can become practitioners who can provide counseling services that are safe and by the procedures and objectives of counseling (safe practitioners).

External skills are skills embodied in the models or approaches to counsels, communication skills, and behavioral skills. The details are included in these skills. (1) the counselor's understanding of the theory and approach to counsels. (2) the counselor's skill in giving certain responses both verbally and non-verbally summarized in counseling communication skills (the skill of paying attention, listening, and influencing); and (3) counselor's skill related to self-behavior, such as how counselors dressed prepare themselves for counseling and using posture and gestures during counseling. This skill referred to as external skills they observed directly.

R.N Jones 2 revealed that there were gaps between the theories taught in the counseling class and good practices in the classroom and practice in the field. Mind skills help the counselor in carrying out each step in the process of counseling and assisting in every decision made by the counselor during the counseling process. According to 3 counseling skills will be more effective if a counselor can control the potential of the mind. Potential thoughts can influence the ways of communication. Counselors and guide teachers can understand that someone can think superconsciously — or think about thinking that can be developed. Counselors and guide teachers will be more efficient to think

2 R.N Jones, Basic Counseling Skills: A Helper's Manual (London: SAGE Publications, Inc., 2003).

3 Jones, Introduction to Counseling Skills. 
when looking at mental processes so that they can train themselves to use and control them.

Other studies 4 related to mind skills have shown the urgency of high mind skills in the counseling process. When the counseling process has happened, the counselor will be very often deciding on important matters both related to the counselee and the counselor himself. However, the counselor often does not realize that he can control thoughts that arise during counseling even in difficult conditions so that many counselors do counseling but the results are not good enough, according to their expectations. Mind skills will help the counselor determine all decisions that help in the counseling process.

The way how to improve these mind skills is to create a product that can be directly used by the counselor and guide teacher. Several ways have been taken to improve knowledge in the application of mind skills. These strategies include Training with JPBM (Student Experience Journal), Portfolio, and Reflection Sheet. These three strategies have several advantages and disadvantages. This research setting was chosen at three schools located in Kudus, Central Java, Indonesia. Based on the results of the preliminary study, several reasons for choosing these settings include (1) counselors and guide teachers claiming to be often confused when providing counseling, consultation services, and even when teaching in class because of poorly guided thoughts. (2) the schools have been fully accredited with the assumption that the ratio of the number of counselors and

4 N. Hidayah, "Process-Audit Dalam Penyelenggaraan Pendidikan Akademik S1 Bimbingan Dan Konseling” (Universitas Negeri Malang, 2009); N. Hidayah, "Penerapan Model Pembelajaran Berbasis Pengalaman Untuk Mengembangkan Mind Competence Calon Konselor" (Malang, 2012). gan Dan Konseling Universitas Negeri Malang.” (Universitas Negeri Malang, 2013). 
guide teachers to clients are appropriate. (3) the enthusiasm of the counselor in scientific updating in the field of guidance and counseling. (4) counselors and guide teachers need a product that can be used and taught to other teachers for continuity in training.

\section{Method}

This study uses a model of research and development $(\mathrm{R} \&$ D). According to5, research and development is to find, develop and validate a product. As for6, development research is research that is used to produce a product and test the effectiveness of certain products. According to 7 , development research is a process or steps to develop a product or perfect existing product. This development research was made for using these three strategies. The result of this study is a guidebook product that is expected to make it easier for counselor and guide teacher in MTsN 1 Kudus, MTsN TBS and SMP Muhammadiyah 1 Kudus to improve their thinking skills/mind skills.

The development model used in the study developed the guidance counselor for prospective counselors to improve the skills of administering counseling adapted from the procedure of 8

According to 9 research and development (R \& D), procedures consist of two main objectives, namely: (1) developing products and (2) testing the effectiveness of products

5 Sugiyono, Metode Penelitian Pendidikan Pendekatan Kuantitatif, Kualitatif, $R$ Dan D. (Bandung: alfabeta, 2012).

6 J. Creswell, Educational Research Planning, Conducting and Evaluating Quantitative and Qualitative Research. (New York: University of Nebraska Lincoln Pearson, 2012).

7 Sukmadinata., Metode Penelitian Dalam Pendidikan (Bandung: alfabeta, 2012).

8 M.D Borg, R. \& Gall, Educational Research An Introduction, ed. White Plain (New York: Longman Inc, 2009).

9 Borg, R. \& Gall. 
in achieving goals. The first objective is called the development function, while the second objective is called the validation function. The development process can stop until the stage of producing a product through limited trials, only such products cannot be used widely and sustainably. Therefore, the product needs to be validated. There are ten steps in implementing research and development strategy. The ten steps are as follows: (1) initial research and information gathering; (2) planning; (3) development of initial product formats: (4) initial product revisions; (5) initial product test; (6) product revisions; (7) field trials (8) revisions to the results of field trials (9) final products or improvements to final products; and (10) dissemination and implementation. 10 Each development can choose and determine the right steps for its research based on the conditions and constraints. 11 In line with Dwiyogo, according to12, this research model can also be modified into three steps. The modifications to these steps include, (a) Phase I: preparation, including needs assessment, literature study, determining the purpose of development and preparing the necessary materials; (b) Phase II: implementation, including drafting the product and (c) Phase III: trials, including expert tests, prospective user trials and small group tests.

\section{The Nature of Counseling}

Etymologically the term counseling comes from Latin, namely, Concilium, which means "with" or "together" which is arranged with "accept" or "understand". Whereas in the AngloSaxon language, the term counseling comes from "sellan" which

10 Borg, R. \& Gall.

11 Dwiyogo, Konsep Penelitian Dan Pengembangan (Malang: Universitas Negeri Malang, 2004).

12 Sukmadinata., Metode Penelitian Dalam Pendidikan. 
means "surrender" or "deliver"13. Counseling is a channel for giving guidance. In counseling a discussion / discussion is held between a counselor (counselor) with one person (individual counseling) or with several people at the same time (group counseling). 14 The person served is called counselee. The discussion revolves around the problem / difficulty / problem that is being faced by someone the counselor helps that person to find a solution to the problem. Counseling is a professional service that has goals in every process that is undertaken. Briefly, the main purpose of using counseling skills is to help counselees develop personal skills and inner strength so that they can create happiness in their own lives and those of others15. Counseling as a process where counselors use counseling skills to assist counselees and make counselees feel supported and understood 16, help counselees clarify and broaden their understanding of something, help develop and implement strategies to change how counselees think, behave, and feel so that they can achieve a predetermined goal 17 .

The purposes of using counseling skills is divided into five different goals 18 namely: (a) Supportive listening. Supportive listening is a goal that refers to the peak skills to be willing and able to listen the counselee, take some views and perspectives of the counselee and sensitively show that they (counselees) have

13 Prayitno, Pelaksanaan Bimbingan Dan Konseling SLTP (Jakarta: PT.Ikrar Mandiri Abadi, 2014).

14 W.S. Winkel, Bimbingan Dan Konseling Di Institusi Pendidikan (jakarta: Gramedia, 2015).

15 Jones, Introduction to Counseling Skill.

16 G Corey, "Theory and Practice of Counseling and Psychotherapy," 2015.

17 Jones, Introduction to Counseling Skill.

18 Jones, Basic Counseling Skills: A Helper's Manual. 
been heard accurately. Counselors with good listening skills can keep the counselee calm down; relieve suffering, treat psychological injuries from counselee problems; (b) Manage problematic situations. The counselee that comes to the counselor brings problems. Problems faced by counselees are influenced by various situations and conditions that are often very complicated. Counselors and counselees together identify problematic situations that are being faced. Based on this situation, the counselor can create a comprehensive problem frame so that the counselee understands the situation at hand. (c) Problem management. Although some problems are trivial, many other problems may be bigger and more complex than the specific situations in them. (d) Change bad skills that create problems. Skills in dealing with problems must be taught, because skills cannot be obtained without a learning process and experience. (e) Realize the changes in the philosophy of life. The management process of managing a problematic situation and changing skills in problem solving needs to become a habit whenever it encounters a problem, and it is one of the life philosophies of the counselee. This is one of the main goals of counseling skills.

\section{Mind Skills}

The term mind skills, which Raka Joni called mind competence is dexterity to respond contextually, which leads to problem solving in counseling 19. In line with this, 20 explained that mind skills are a series of actions that must be carried out by a professional counselor so that the counseling can take place appropriately and effectively. With this process, a counselor can review the actions that have been carried out and make certain

19 T.R. Joni, "Resureksi Pendidikan Profesional Guru.” (LP3 Univeristas Negeri Malang, 2008).

20 Jones, Introduction to Counseling Skill. 
reflections on the next action on an ongoing basis stored in the cognition of the counselor concerned as experience or knowledge about how to do counseling. 21 describes that there are six components of mind skills that should be owned by the counselor, as follows.

\section{Creating rules}

Jones 22 explains that creating a rule that helps is to create rules that are realistic and preferential, replacing demanding or absolute regulations. Preferential regulations are flexible and provide alternative choices, different from irrational demands. It is different from demanding or absolute regulations which means that the regulation is rigid, absolute, and has no other choice but to be carried out. Regulations that help in counseling have an influence on the counselor, which can put themselves in accordance with the portion, apply the basic attitude of the counselor as it should be, do not force yourself when doing counseling, which leads to achieving the goal of counseling.

\section{Creating perceptions}

Perception is defined as the level of accuracy or accuracy of a person in realizing and evaluating themselves, others, and situations. The concept of perception is emphasized in the concept of proportional thinking. This includes testing reality about the perceptions of oneself, others, and situations 23 . Creating perceptions that help focus on how a person's level of accuracy is aware of himself compared to being aware of others. How high can a person be able to judge himself compared to judging others.

21 Jones, Basic Counseling Skills: A Helper's Manual.

22 Jones.

23 Jones, Introduction to Counseling Skill. 


\section{Creating self-talk}

Conversations that occur in counseling, at least consists of three things, namely: (1) general conversation between the counselor and the counselee; (2) conversations in the counselee; and (3) conversations within the counselor. Selftalk or self-talk that involves mental processes that are included in the counselor's thinking skills. All processes of verbal thinking are included in the type of speech themselves. Self-talk in the counseling process is emphasized on how to focus on managing self-talk that is in the head of the counselor, so that the counselor can hold counseling without loose direction 24. The function of self-talk, in particular, is to focus the counselor's thinking, so that it is able to capture what the counselee says appropriately, able to respond appropriately to everything the counselee shows through his words and behavior, not playing with his own imagination when doing counseling, able to empty his mind except what was told by the counselee, so that counseling does not run away everywhere, can be focused on the counselee problem and the achievement of the goal of counseling.

\section{Creating a helpful visual image}

When experiencing a feeling or sensation that is significant, a person usually describes what they feel in their mind. It could be that what others tell is also responded by describing it in the head using certain pictorial images. If someone is can be involved in what others say, they will make a best describing picture in their head. Another dimension that must be done by the counselor is to eliminate other negative

24 Jones. 
pictorial images that are deemed unnecessary, so can not interfere with the course of counseling.

\section{Creating helpful explanations}

Mind skills explore the ability of counselors to be able to create helpful explanations. The explanation means an explanation of the problems it faces, brought by the counselor, and an explanation of the counselee. Mind skills bring the counselor to explain himself what he is helping his counselor 25 Creating explanations that help involve an explanation of the causes of the problem that originated with oneself and avoid explanations that are contrary to the real cause. Not using excuses or reasons that are sought or hyperbole, but instead using various relevant considerations constructively to modify explanations 26

\section{Creating hope that helps}

Humans predict what will happen in the future, so they can influence and control it. As a result, humans need to create expectations about the consequences of communication and behavior. How their expectations for the future will affect their own feelings, other people's feelings, physical reactions, opinions, and their ability to communicate with others. In counseling skills, creating helpful expectations means that the counselor creates realistic expectations about the level of his own ability to deal with difficult situations and people.

\section{Stages in Experiential Learning Model Training}

The choice of a training model as a strategy for training thinking skills is important in a guide. The selection of an

25 Jones.

26 Jones, Basic Counseling Skills: A Helper's Manual. 
appropriate training model will also contribute to whether the training can be applied properly or not. The selection of training models using experiential learning contains several aspects, including: (1) knowledge (concepts, facts, information); (2) activities (application in activities); and (3) reflection (analysis of the impact of activities on individual development) 27.

\section{Result}

This study produced a mind skills training guide for counselors and a teacher guide. The guide is in the form of two books, namely a guide for facilitators and counselors. The results of the preparatory phase consist of data on the needs assessment and the results of the literature study. Needs assessment was carried out to determine the need for mind skills training with experiential learning models for counselors and teacher guides in Kudus 1 MTsN, MTsN TBS and Kudus Muhammadiyah 1 Middle School. Need assessment was carried out with interviews with counselors and teacher guides. Aspects of interviews include: 1) what is known about mind skills, 2) whether to get material about mind skills, 3) whether the strategy to train mind skills has been obtained, 4) what methods are used by lecturers in applying mind skills, 5) Need a guide mind skills in counseling to improve the quality of counseling. The results of the interview regarding whether or not the mind skills guide needed is that and guide teacher counselor have heard about mind skills but have not received material about mind skills, other results show that participants need training in mind skills to improve the quality of counseling. The conclusion from the interview is that participants

27 D. Kolb, Experiential Learning: Experience as The Source of Learning and Development. (New Jersey: Prentince Hall, Inc., 1984). 
need mind skills training in order to improve the quality of counseling.

The mind skills training guide was developed by referring to the needs of research subjects based on the results of interviews and literature studies. Literature studies are conducted by examining theories and concepts as a theoretical foundation that strengthens the products developed. The theoretical foundation used as material for mind skills training guides with experiential learning models for participants Guidance and Counseling is the concept of Basic skills / mind skills by Richard Nelson Jones 28 $\& 29$ the concept of various counseling approaches by Willis 30 experiential concepts learning by David Kolb 31.

The stage of testing or product validity testing by two experts namely material experts and media experts produces an assessment with categories that have fulfilled the acceptability aspects which are very precise, very useful and very appropriate. The stage of testing prospective users by two lecturers of counseling clusters resulted in an assessment with a category that has fulfilled the acceptability aspect, which is very precise, very useful and very appropriate. The small group test phase produces a percentage assessment. The results of the analysis showed that three trainees had a score of $89 \%$ in the "very good" category. Furthermore, the results of the analysis of three other participants showed a percentage of $74 \%$ in the category of "good", $84 \%$ and $95 \%$ in the category of "very good". So the overall average yield is $87 \%$ in the "very good" category.

28 Jones, Basic Counseling Skills: A Helper's Manual.

29 Jones, Introduction to Counseling Skill.

30 S Urbani et al., "Skills-based Training and Counseling Self-efficacy," Wiley Online Library, n.d.

31 Kolb, Experiential Learning: Experience as The Source of Learning and Development. 
From the results of the assessment of mind skills training by six counselors and a guide teacher showed that the training guide received a percentage of $87 \%$ with the title "very good". Participants experience changes in understanding the concept of mind skills, giving rise to six components of mind skills, distinguishing between learning skills that are helpful and not helpful and finally applying mind skills that help in counseling.

\section{Discussion}

Based on the results of expert research and assessment of prospective users, the product of developing mind skills training guides with experiential learning models has fulfilled the acceptability aspect. This is indicated by the results of expert test evaluations, prospective user test assessments and assessment and results of discussions with training participants about the advantages and disadvantages of the product guide.

The product produced is a mind skills training guide with an experiential learning model that is used by facilitators and counselors and guide teachers. The systematics guidelines are as follows: (1) introduction; (2) general instructions; and (3) mind skills training procedures. The training activities are six components of mind skills, namely: (1) regulations; (2) perception; (3) self-talk; (4) visual image; (5) explanation; and (6) hope. Expert tests are carried out by reviewing the products that have been developed, then experts fill the assessment format with 4 value scales in accordance with the Standards for Evaluation of Educational Programs, Projects and Materials32. Then, the assessment was analyzed quantitatively and qualitatively.

32 The Joint Commitee on Standad for Educational Evaluation, Standard for Evaluation of Educational Programs, Projects, and Materials. (New York: McGraw, 2010). 
The expert test results have a number of notes which form the basis for revisions and improvements to the guidelines before being tested to prospective users. The note is in the form of criticism, suggestions and feedback on the product being tested. The note given by the expert in the field of guidance and counseling is that the use of the term intervention strategy should not be distorted by technique, in the context of this product is experiential learning. The rest, both the formulation of the objectives and the substance of the product, has been felt to fulfill the acceptability aspect. The notes provided by experts in the development of educational media are the colors for facilitator and participants guidance made different in order to make it easier for users to distinguish guides for facilitators and participants. The rest for media attractiveness has been felt to fulfill the acceptability aspect.

The results of the assessment of the two expert tests state that the guidelines have met the exact aspects of the selection of intervention models / strategies because through the experiential learning model, trainees gain knowledge effectively through hands-on experience. This is in accordance with learning theory according to experiential learning, namely learning as the process of birth of knowledge through changing forms of experience. Knowledge arises from a combination of understanding and transformation of experience 33.In addition, the guidelines have met the usability aspects based on the findings of previous research that mind skills need to be trained in order to improve the quality of counseling service quality 34 . Guides are also considered by experts according to the need for the application of

33 Kolb, Experiential Learning: Experience as The Source of Learning and Development.

34 Radjah.CL, "Metakognisi Konselor Dalam Kegiatan Layanan Konseling Di Sekolah" (Universitas Negeri Malang, 2012). 


\section{0 | Supa'at \&Khilman}

mind skills in counseling, this answers the results of a preliminary study conducted by 35 about the gap between theories taught in counseling subject groups with the practice of applying theory in the field, especially in mind skills.

Associated with the results of the assessment of media attractiveness, refers to variations in the use of colors to attract readers. This is based on the theory of color psychology that describes color as one aspect to influence someone's changing feelings, influencing perspectives and building an atmosphere of comfort 36.

Based on the results of expert test assessments, product revisions and improvements are carried out with the aim of preparing products to be tested to prospective users. The results of the assessment by the two prospective users have met the acceptability aspects, namely, accuracy, usability and suitability. Discussions were also held to strengthen the judgments made by prospective users.

The discussion and feedback result shown that the keywords in the evaluation and reflection section, which must be carried out carefully because they relate to the conditions of the trainees, facilitators must pay attention to the readiness of trainees and minute to minute decisions by trainees, mind skills training does not run rigidly. The rest, advice from the first prospective user relates to one image quote about mind skills.

The results of the assessment by prospective users indicate that the guidelines have met the acceptance criteria, especially in evaluation techniques. This is in accordance with the study of the

35 Naning, "Internalisasi Keterampilan Berfikir Pada Mahasiswa Bimbingan Dan Konseling Universitas Negeri Malang."

${ }_{36}$ C.L Franklin, Colour and Colour Theories (London: Routledge, 2001). 
theory put forward by 37 which states that in one of the realms of education is the cognitive domain, which contains evaluation. Evaluation is intended to carry out various analyzes of shortcomings and strengths and make improvements to the material that has been trained.

Feedback, suggestions and feedback from prospective users is the material for revising the product before the small group test. The small group test was conducted eight times. From the results of mind skills training to six Guidance and Counseling paticipants showed changes in understanding the concept of mind skills, giving rise to six components of mind skills, distinguishing mind skills that help and not helping and applying mind skills that help in counseling. These results are obtained based on discussions and interviews conducted with participants. However, there are some feedback notes which include: (1) suggestions for more attractive covers; (2) adding images to make it easier to understand the material and; (3) language, the display used to be easy to understand.

Based on the results of an assessment conducted by six participants stated that the image illustrations are interesting. This is in accordance with the study of image media. According to38, the benefits of image media in the learning process are as follows, (a) Image media can clarify the presentation of messages and information so and improve learning processes and outcomes; (b) Image media can improve and direct children's attention so it can lead to learning motivation. Inputs, suggestions and feedback from training participants are the material for revising the final product that meets aspects of accuracy, usability and suitability.

37 B. S. Bloom, Taxonomy of Educational Objectives: Handbook 1, Cognitive Domain, 1st ed. (New York: David McKay, 2009).

38 Azhar Arsyad, Media Pembelajaran. (Bandung: Rajawali Press, 2009). 


\section{Conclusion}

Based on the objectives and results of the discussion in the research that has been carried out produces a mind skills training guide with an experiential learning model for counselors and a guide teacher in order to improve counseling skills in a theoretical and practical manner. In general, development products that are assessed by experts and prospective users have met the acceptance criteria which include three aspects, namely aspects of accuracy, aspects of usability and aspects of conformity. Third. the results of the assessment of mind skills training by six counselors and a guide teacher showed that the training guide received a percentage of $87 \%$ with the title "very good". Participants experience changes in understanding the concept of mind skills, giving rise to six components of mind skills, distinguishing between learning skills that are helpful and not helpful and finally applying mind skills that help in counseling.

Suggestions and criticisms for this article are focused on the effectiveness test through an experimental approach with the aim of testing the results and impact on the product that has been made. In addition, the stage of dissemination as the final phase of research still needs to be expanded so that the acceptability aspect can be further enhanced. So far, dissemination efforts have been carried out by being presented through limited scientific forums such as workshops, training, seminars and call of papers. Another input that needs to be considered is making the training manual integrated with technology and information such as e-books or even smartphone applications that are more accessible to users. 
Supa'at \& Khilman | 313

\section{References}

ABKIN. Penataan Pendidikan Profesional Konselor Dan Layanan Bimbingan Dan Konseling Dalam Jalur Pendidikan Formal. Jakarta: Depdiknas, 2008.

Arsyad, Azhar. Media Pembelajaran. Bandung: Rajawali Press, 2009.

Bloom, B. S. Taxonomy of Educational Objectives: Handbook 1, Cognitive Domain. 1st ed. New York: David McKay, 2009.

Borg, R. \& Gall, M.D. Educational Research An Introduction. Edited by White Plain. New York: Longman Inc, 2009.

Corey, G. "Theory and Practice of Counseling and Psychotherapy," 2015.

Creswell, J. Educational Research Planning, Conducting and Evaluating Quantitative and Qualitative Research. New York: University of Nebraska Lincoln Pearson, 2012.

Dwiyogo. Konsep Penelitian Dan Pengembangan. Malang: Universitas Negeri Malang, 2004.

Franklin, C.L. Colour and Colour Theories. London: Routledge, 2001.

Hidayah, N. "Penerapan Model Pembelajaran Berbasis

Pengalaman Untuk Mengembangkan Mind Competence Calon Konselor." Malang, 2012.

—. "Process-Audit Dalam Penyelenggaraan Pendidikan Akademik S1 Bimbingan Dan Konseling." Universitas Negeri Malang, 2009.

Jones, R.N. Basic Counseling Skills: A Helper's Manual. London: SAGE Publications, Inc., 2003.

Jones, R.N. Introduction to Counseling Skill. London: SAGE Publications, Inc., 2005.

Joni, T.R. "Resureksi Pendidikan Profesional Guru." LP3 Univeristas Negeri Malang, 2008. 
Kolb, D. Experiential Learning: Experience as The Source of Learning and Development. New Jersey: Prentince Hall, Inc., 1984.

Naning, R. "Internalisasi Keterampilan Berfikir Pada Mahasiswa Bimbingan Dan Konseling Universitas Negeri Malang." Universitas Negeri Malang, 2013.

Prayitno. Pelaksanaan Bimbingan Dan Konseling SLTP. Jakarta: PT.Ikrar Mandiri Abadi, 2014.

Radjah.CL. "Metakognisi Konselor Dalam Kegiatan Layanan Konseling Di Sekolah." Universitas Negeri Malang, 2012.

Sugiyono. Metode Penelitian Pendidikan Pendekatan Kuantitatif, Kualitatif, R Dan D. Bandung: alfabeta, 2012.

Sukmadinata. Metode Penelitian Dalam Pendidikan. Bandung: alfabeta, 2012.

The Joint Commitee on Standad for Educational Evaluation. Standard for Evaluation of Educational Programs, Projects, and Materials. New York: McGraw, 2010.

Urbani, S, MR Smith, ... CD Maddux - Counselor Education, and undefined 2002. "Skills-based Training and Counseling Self-efficacy." Wiley Online Library, n.d.

Winkel, W.S. Bimbingan Dan Konseling Di Institusi Pendidikan. jakarta: Gramedia, 2015. 